University of Nebraska - Lincoln

DigitalCommons@University of Nebraska - Lincoln

Investigations of the Ichthyofauna of

Nicaraguan Lakes

Papers in the Biological Sciences

1976

\title{
Ontogeny of Parent-Contacting in Young Cichlasoma Citrinellum (Pisces, Cichlidae)
}

\author{
David L. G. Noakes \\ University of Guelph \\ George W. Barlow \\ University of California - Berkeley
}

Follow this and additional works at: https://digitalcommons.unl.edu/ichthynicar

Part of the Aquaculture and Fisheries Commons

Noakes, David L. G. and Barlow, George W., "Ontogeny of Parent-Contacting in Young Cichlasoma Citrinellum (Pisces, Cichlidae)" (1976). Investigations of the Ichthyofauna of Nicaraguan Lakes. 31. https://digitalcommons.unl.edu/ichthynicar/31

This Article is brought to you for free and open access by the Papers in the Biological Sciences at DigitalCommons@University of Nebraska - Lincoln. It has been accepted for inclusion in Investigations of the Ichthyofauna of Nicaraguan Lakes by an authorized administrator of DigitalCommons@University of Nebraska Lincoln. 
Reprinted from

BEHAVIOLR 46(3-4):221-255

E. J. Brill, Leiden, 1973

\title{
ONTOGENY OF PARENT-CONTAGTING IN YOUNG CICHLASOMA CITRINELLUM (PISGES, GICHLIDAE)
}

\author{
by
}

\author{
DAVID L. G. NOAKES ${ }^{1}$ ) and GEORGE W. BARLOW ${ }^{2}$ ) \\ (Department of Zoology and Museum of Vertebrate Zoology, \\ ('niversity of California, Berkeley, Calif., U.S.A.) \\ (With 6 Figures) \\ (Rec. 5-VI-I972)
}

\section{INTRODUCTION}

There is an extensive literature on cichlid fish behavior, but most of this treats the behavior of adults (see BREDER \& Rosen, I966, for example). Much of this is based on laboratory observations with little corroborative information from field studies. Recently there has been an increasing trend to study the development of behavior, in cichlids as in other animals. In part this results from the 'nature-nurture' controversy regarding factors controlling behavior (e.g. KRUIJT, I964). However, there is also interest in the study of young animals for their own sake (e.g. WARD \& BarLow, 1967).

The present study was undertaken to determine the factors controlling a specific behavior of young Cichlasoma citrinellum. During their first week of free swimming they begin to contact the parent, as though feeding from the surface of their bodies.

Behaviors by which young cichlids come into deliberate contact with parents have been described for several species. In three mouthbreeding species of Tilapia, young make contact with the parents (BAERENDS \& BaERENDS-vaN Roon, 1950; Peters, 1963; Ward \& Barlow, 1967). In the first two cases, this is an escape reaction, the movement of young back into the parent's

I) Present address: Zoology Department, University of Guelph, Ontario, Canada.

2) Thanks to all the 'Berkeley Buntbarsche Buddies' for their contributions, large or small, to this investigation. Special thanks to JerRy MERAI for his contributions in and from the field. Dick Green's statistical advice was highly significant. The German summary was kindly prepared by WERNER LOHER. The research and writing were supported in part by grants-in-aid to Barlow from the National Science Foundation (GB 13426), and by a Teaching Assistantship to D.L.G.N. from the University of California. Part of the writing was carried out by D.L.G.N. since joining the Zoology Department, University of Edinburgh, and grateful acknowledgement is extended for use of space and facilities

Behaviour XLVI 
mouth. The contacting of parents by young Cichlasoma biocellatum, a substrate breeding species, has also been described as a fright response (KüHME, 1962).

In the discus fish (Symphysodon discus), another substrate breeding species, the 'clinging' or 'riding' of young on the parents has been known for some time (Hildemann, I959). Ward \& Barlow (1967) investigated a similar behavior in yet another substrate breeding species, Etroplus maculatus. Further study of this latter species has been reported by QUERTERMUS \& WARD (1969).

In both $S$. discus and E. maculatus, young are apparently dependent on this contacting of parents, at least under the usual laboratory circumstances. Young isolated from parents fail to grow or survive (HILdEMan, I959; WARD \& BARLow, I967). In contacting the surface of the parents, young apparently obtain mucus and/or other essential material. Studies of $E$. maculatus have shown the details of two separate motor patterns in the behavior, and how through time they change differently with factors such as feeding and age of young.

The contacting behavior of young $C$. citrinellum has a superficial resemblance to the behaviors of young $S$. discus and E. maculatus. However, there are the further dimensions of polychromatism and sex of parents. Preliminary observations revealed that young $C$. citrinellum have a discrete, readily observable behavior directed to the parents. This behavior seemed to change with age, and to be directed differentially to parents of different sex and color. It therefore seemed an accessible and worthy problem for further study.

\section{SYNOPSIS OF BEHAVIOR OF CICHLASOMA CITRINELLUM}

Cichlasoma citrinellum (GÜNTHER, I864) is a polymorphic species native to Nicaragua, Central America. Details of its taxonomy, xanthic polychromatism, distribution and life history are to be published elsewhere (G. W. BARLow, in prep.). About $8 \%$ of the adult population from which our laboratory stock is drawn are partially or completely xanthic, which we term gold morphs. The remaining $92 \%$ we refer to as normal or grey morphs.

Reproduction is generally typical of a substrate breeding species (BAERENDS \& BAERENDS-VAN Roon, 1950). Young begin free swimming about one week after the eggs are spawned. On about Day 4 of free swimming the young begin contacting: They orient toward, approach, move about close to, and contact the parents' bodies. The young apparently nibble surface material from the parents. The motor patterns used appear identical to those of young foraging on the bottom and sides of aquaria. 
Contacting by young $C$. citrinellum differs from the 'riding' or 'clinging" by young $S$. discus. Young discus stay close to the surface of the parents' bodies, and they appear to nibble at the surface from time to time (pers. observ.). This close, continuous association between young and parents has been mentioned by others (illustration in Hildemann, I959; Sterba, i962).

Contacting in $C$. citrinellum resembles micronipping by $E$. maculatus in that it is a discrete behavior, but one that is continuously expressed. It differs in that it is a more graded behavior and so necessitates a different method of recording observations. Further comparisons will be drawn in later discussion.

Parental care continues until the young are about five weeks old. Young will go on contacting parents left with them. But contacting then results in surface wounds on the parents. Not surprisingly, parents then show increasing avoidance of young. Parental care, however, begins to wane even before this. In the field no families with young judged to be older than about five weeks were seen.

During courtship, the adult color pattern changes to that which typically remains for the parental period. The spotted grey morphs develop seven conspicuous dark vertical bars, with very light interspaces, along each side of the body. Xanthic fish show no obvious color change.

\section{FIELD OBSERVATIONS}

Fish were observed in Lakes Apoyo and Jiloá (July-August, 1969), two relatively small crater lakes in north central Nicaragua (details in BARLow, in prep.) These lakes are adjacent and similar to Lake Masaya, the source of our laboratory stock. Turbid water in Lake Masaya made underwater observations there impossible.

Observations were made while skin diving with snorkels and face masks in relatively shallow water ( $10 \mathrm{~m}$ deep, or less) around the edges of the lakes.

Only pairs in which both male and female were grey morphs were observed. Detailed observations were recorded for 24 pairs in the two lakes. Each pair was watched for Io to 20 minutes, some for as long as 45 minutes. Some pairs were observed more than once, the maximum being one pair watched three times over a period of one week. Such pairs were recognized by their tendency to remain in one location, by size and number of young, and by scars and/or distinctive marks.

In general, the area defended by a breeding pair was about one meter or less in diameter. In fact, this corresponds remarkably well to the size of aquaria most used in our laboratory studies (90 by 60 by $45 \mathrm{~cm}$ deep). Presence of breeding territories seemed to depend more on suitable cover 
(some sort of cave among rocks), than on such things as depth of water or distance from shore. Colors of breeding and nonbreeding fish were as in the laboratory. Observations indicated the advantage for the young to stay in a cohesive group close to one or both parents. Juvenile Cichlasoma managuense and $C$. citrinellum, and Gobiomorus dormitor adults and juveniles, were omnipresent and took stray young whenever they could. In a few cases when the close approach of an observer frightened the parents away from their young, all the fry were eaten by these predators within minutes.

Contacting the parents was seen as a regular behavior of the young. This confirms contacting as normal behavior for this species, and is the first confirmation of such behavior in nature in cichlids.

When it was possible to estimate numbers of contacts to parents over several minutes, the young were apparently contacting the male more than the female (both lakes). In some cases the number of contacts were counted for a series of short periods ( Io to $\mathrm{I}_{5}$ seconds each). In these cases the number of contacts was a high as 8 to ro to the male as compared to only $\mathrm{r}$ to the female (Lake Apoyo). These quantitative observations are so few in number as to be questionable, were it not that they agree fairly well with laboratory data.

In Lake Jiloá three pairs with young were observed in close proximity (within $10 \mathrm{~m}$ along the shore), immediately in succession on one day. All had about the same number of young, which were judged to be within a week of, each other in age. The young of two of these pairs were not observed to contact the parents at all, even though they were watched continuously at close range for up to 45 minutes each. However, it was noted that about 90\% of the young of these pairs were foraging on the bottom at any time during the observations. The young of the third pair were contacting the parents, but at a lower rate than similar young in Lake Apoyo (about 30-60 per minute in Jilóa; about 6o-I80 per minute in Apoyo). Also, only about $50 \%$ of these young were foraging on the bottom at any time during the observation. In Lake Apoyo only about Io\% of the young in each family were foraging on the bottom at any time.

Young in Lake Jiloá might have been contacting less because their foraging activity of necessity excluded other behaviors at the same time. But there is also the possibility that contacting is an alternate source of nutriment for the young. The 'Aufwuchs' (encrusting algae) growing on the bottom in Lake Jiloá was noticeably thicker and more luxuriant than in Lake Apoyo. When much food is present the young may contact less than when little food is present. 


\section{LABORATORY STUDIES}

\section{MATERIALS AND METHODS}

Some confusion exists as to the status and correct name for this specics. Several species names have heen proposed, based largely on body color and slape and on lip size (c.f. (rînther, I869). This is both a nomenclatorial and a systematic problem and this study is not aimed at resolving it. For both biological and taxonomic reasons we consider that we arc dealing with one polymorphic species and that Cichlasoma citrincllum is the appropriate nane.

Twenty-scren juveniles and adults of both sexes and both color pliases, used in this :turdy, hare heen deposited in the collections of the British Museum of Natural History (numbers ig68.I.I2.I, I068.1.12.6 - 1068.I.12.3I).

Adult fish used were cither wild-caught from Lake Masaya, Nicaragua, or first rencration lahoratory hed from such stock. The lab bred fish were about two years old at the beginning of the study. The wild-caught fish were one or two years older.

To make experiments less confusing and analysis of the problem simpler, fish were sclected as follows. Normal colored fish were individuals with the species-typical grey und black color pattern with no trace of xanthism. Gold colored individuals were uniformly xanthic with no grey or black markings. The basic color of the gold fish encompased a fairly narrow range, generally a vellowish-orange similar to the gold color of the common roldfish (Carassits auratus).

Standard lengths (Hubrs \& LAGr.er, I958) of adults used were from I07 to I8I mm. Males are sencrally larger than females as adults, but there is considerable overlap in rizes. The male of a freely mated pair is typically larger than the female.

Pretreatment.

Stock animals were kept in screen cages in an outdoor pool with continuous, slow exchange of water $\left(28^{\circ} \mathrm{C} \div 2^{\circ}\right)$. Light and photoperiod were the natural outdoor cycle at Berlocley, California. Some fish were held at times in a controlled temperature-photoperiod room $\left(28^{\circ} \mathrm{C} \pm \mathrm{I}^{\circ}\right.$; I2 : I2 hours light: dark, plus $\mathrm{I} / 2$ hour 'twilight' at beginning and end of photoperiod).

Stock animals were fed twice daily a varied diet of Clark's Tront Chow (J. R. Clark (o., Salt Lake City, Utah), commercial dried food (Tetramin), live adult brine shrimp (Artemiu salina), live earthworms (Lumbricus sp.), whiteworms (Enchytracus sp.), all-bran cereal and wheat germ.

Fxperimental conditions.

Aged tap water, plus $2-2.5 \mathrm{gm} / \mathrm{I}$ marine salts added; $\mathrm{pH} 6.2-7.5$; heated and aerated i1 reservoirs until needed $\left(28^{\circ} \mathrm{C} \pm 1^{\circ}\right)$ was used.

Light was provided by fluorescent tubes, 3o watt "Warm White," on at 0800 , of $f$ at 200 hours, $20 \mathrm{~cm}$ above the surface of the water.

Adults and young were fed twice daily, unless noted otherwise, at times depending upon experiment at hand. Adults were fed mainly live adult brine shrimp, earthworms, whiteworms and dried food (Tetramin). Young were fed live brine shrimp nauplii, nowdered dry food (Tetramin), and occasionally microworms (Anguillula sp.).

Aquaria were stainless stcel frame, all glass construction, with opaque PVC (polyvinyl(hloride) spawning shelters or broken flower pots as cover; light colored medium sized wravel $3-4 \mathrm{~cm}$ deep on the hottom in early observations, but none in later tests. Filtration was ly nutside gravel filter beds or charcoal and plastic wool corner filters. Some later tests emploved camouflaged viewing ports on fronts of aquaria, others did not; all aquaria had back and both ends covered with thick blue paper, with wavy black lines (1) represent plants (Fallisneria sp.) drawn on the side of the paper exposed to the fish. Aquaria were set 11 in locations to minimize disturbances to the fish. 
Breeding these fish in the laboratory is difficult. They are large, and can inflict severe injuries on each other. Putting a male and female together in an aquarium usually results in the male killing the female within a matter of hours. Consequently, the fish were prevented from physical contact while they were allowed to settle down and go through the initial stages of courtship. Individuals selected for a particular mating were put into an aquarium, separated by a plastic screen partition (Saran, MS Iog). When the fish were courting actively the screen was removed. Spawning soon followed in most cases.

Recording of contacting.

The term contacting refers to an action of the young fish in which the mouth makes contact with some part of the parent. The young appear to be nibbling material from the surface of the parents by this behavior. While this is an overt and discrete motor pattern(s), it often occurs with such frequency that it is difficult to keep track of individual young. Also, it is sometimes difficult to determine the end points of the behavior because the young fish may bite and hold onto the parent for one or two seconds, or it may show a rapid series of contacts of short duration. So rather than attempt to record the absolute number of contacts, interval sampling was used.

Each observation period lasted 20 minutes. In 5 to 10 minutes the fish were accustomed to the observer's presence, and recording began. At the signal from an electronic metronome, the number of young actually in contact with one parent at that instant was recorded. Observations alternated between parents at successive 5 -second intervals. The parent to be observed initially was determined by the flip of a coin. Each 20-minute observation gave a total of $\mathrm{I} 20$ scores for each parent.

The number of contacts recorded this way is much less than the total number of contacts by the young fish in a 20-minute period. However, all that was desired was a reliable index to compare contacts to the female to those to the male parent, and changes over time, as in feeding, and during the day.

Direct observations were supplemented by photographs taken with a $35 \mathrm{~mm}$ still and a $16 \mathrm{~mm}$ ciné camera.

\section{BEHAVIOR OF YOUNG IN UNDISTURBED FAMILIES}

\section{PROCEDURE}

These observations were to establish and delimit the phenomenon, to produce a baseline for succeeding tests, and to point out the most profitable lines of investigation to be followed.

Pairs of fish, set up as described, were allowed to spawn and raise their young. No adjilustments in numbers of young or manipulations of parents were done. Fifteen pairs were observed; four normal male $X$ normal female, three normal male $\times$ gold female, five gold male $X$ normal female and three gold male $\times$ gold female.

Aquaria were of two sizes. One contained about 1201 ( 90 by 40 by $35 \mathrm{~cm}$ deep), the other contained about 2401 ( 90 by 60 by $45 \mathrm{~cm}$ deep). Pairs of each color combination were observed in each size aquarium.

\section{RESULTS}

Each pair was watched until the young were about six weeks old (since spawning) and the parents were showing damage. The parents then spent much time swimming away, avoiding the young, or attempting to hide from them. Observations were discontinued before such obvious disruption of behavior occurred. 
In some observations, the rate of contacting was low and there were relatively few contacts for the 20 -minute period. An examination of protocols suggested that this might be related to a recent feeding of the young. This was the basis for later investigations of the relationship between feeding and contacting. An arbitrary lower limit was set for analyzing these results. Data from observations yielding less than 25 total contacts to male and female were not included in analyses. At most, this excluded two or three observations of a total of 10 to 20 for each pair of fish.

Statistical tests applied to the data included the Spearman rank correlation coefficient, $r_{s}$, the Wilcoxon matched pairs sign rank test, and the MannWhitney U test (SIEGEL, I956).

Values given are either ranges for particular days or size of tanks, or median values for successive three-day periods of age of the young fish. For example, observations for Day 6 to Day 8 are expressed as a median for Day 7.

Since aquaria of two sizes were used, the first question asked was whether or not this had any effect on the amount of contacting by young fish. It seemed logical that young might contact parents more in a smaller aquarium because they were kept closer together. All observations for all pairs, grouped as to size of aquarium used, were compared (Table I). Young in smaller aquaria contacted parents significantly more than those in larger aquaria $(\mathrm{p}<0.00 \mathrm{I}, \mathrm{Mann}-\mathrm{Whitney} \mathrm{U}$ test $)$.

\section{TABLE I}

Total number of contacts, in 20-minute observation periods, by young fish in aquaria of different sizes

\begin{tabular}{cccc} 
& \multicolumn{2}{c}{ Total Number of Contacts } & \\
Aquarium (liters) & range & median & $N$ \\
120 & $5-637$ & 264 & 56 \\
240 & $3-476$ & 88 & I 2
\end{tabular}

The next question was whether or not the contacting behavior changed with age. This we broke into three sub-questions.

(I) Does the total number of contacts per unit time differ for young of different ages? In Table 2 the data are compared in this manner. A Spearman rank correlation coefficient shows no significant correlation between age of the young fish and total number of contacts $(\mathrm{p}>0.20)$. 
TABLE 2

Total number of contacts, in 20-minute observation periods, by young fish of different ages (age $=$ days free swimming)

\begin{tabular}{crc} 
Age of Young & \multicolumn{2}{c}{$\begin{array}{c}\text { Total } \\
\text { range }\end{array}$} \\
4 & $36-281$ & $\begin{array}{r}\text { Contacts } \\
\text { median }\end{array}$ \\
7 & $3-637$ & 193 \\
10 & $13-540$ & 88 \\
13 & $5-579$ & 234 \\
16 & $8-370$ & 151 \\
19 & $3-425$ & 161 \\
22 & $22-455$ & 94 \\
25 & $46-240$ & 77 \\
28 & $23-200$ & 69 \\
31 & $118-476$ & 90 \\
34 & $49-378$ & 197 \\
& & 265
\end{tabular}

(2) Does the ratio of contacts (male/female) change for different number of total contacts? This question was posed in terms of ratio of contacts because preliminary observations suggested that young were contacting male more than female parents, in some cases more than in others. There was no significant correlation between total number of contacts and the ratio of contacts (male/female) (Table $3, \mathrm{p}>0.20$ ).

\section{TABLE 3}

Median ratio of contacts (male/female) by young fish, grouped according to total number of contacts in 20-minute observation periods

Total Number of Contacts

$25-75$
$76-125$
I $26-175$
I $76-225$
$226-275$
$276-325$
$326-375$
$376-425$
$426-475$
$476-637$

Median Ratio of Contacts
I. 50
I. 52
2.45
I. 46
2.18
1.00
I. 32
I.79
2.32
I. 29

(3) Is the ratio of contacts (male/female) different for young of different ages? This question stemmed from our broad question of changes of behavior with age, as well as from the previous question of differential response to male and female parents. The data for this comparison (Table 4) show a significant positive correlation between age of young fish and ratio of contacts (male/female) $(\mathrm{p}<\mathrm{o} . \mathrm{or})$. 
TABLE 4

$$
\begin{gathered}
\text { Median ratio of contacts (male/female) by young fish of different } \\
\text { ages (age }=\text { days free swimming) }
\end{gathered}
$$

$\begin{array}{cc}\text { Age of Young } & \text { Median Ratio of Contacts } \\ 4 & 1.38 \\ 7 & 1.35 \\ \text { IO } & 1.40 \\ \text { I3 } & 1.35 \\ \text { I6 } & 1.25 \\ 19 & 1.75 \\ 22 & 1.50 \\ 25 & 4.30 \\ 28 & 1.65 \\ 31 & 2.51 \\ 34 & 10.52\end{array}$

The answers to our questions, then, are: ( $\mathrm{I}$ ) there is no significant change in total contacts with age of the young fish; (2) the ratio of contacts (male/ female) is not significantly different for different total number of contacts: and (3) the ratio of contacts (male/female) changes significantly with age-older fry contact the male parent relatively more than do younger fry.

To illustrate this latter relationship more clearly, the data of Table 4 are plotted in Figure I. For the first five values the ratio of contacts is not significantly in favor of either parent. The next two values are at the point of being significantly in favor of the male $(0.07>\mathrm{p}>0.02$; Wilcoxon test). The last four values in Figure $\mathrm{I}$ are all significantly in favor of the male parent $(\mathrm{p}<0.05)$. In short, the young contact the male parent more than the female, the difference increasing with age and becoming statistically significant at about three weeks of free swimming.

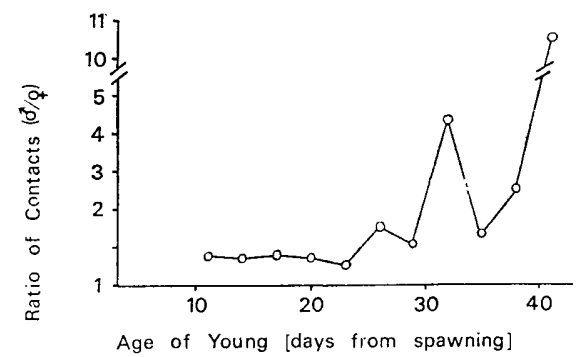

Figure I. Ratio of contacts $(\hat{\delta} / \hat{q})$ for young of different ages, all parental types combined.

Our initial observations had also suggested a differential responsiveness to parents of different color. Hence the data of Figure I were broken down 
according to the colors of the parents and plotted in Figure 2. The normal male $X$ normal female group showed an insignificant positive correlation between the age of the fry and ratio of contacts $(p>0.05)$. These had been the first group observed and unfortunately were terminated sooner than were the others. However, observations taken later on such pairs showed that the young develop a significant preference for the male, with the ratio of contacts increasing with age (see section on deprivation from contacting). The gold male $\times$ normal female yielded an insignificant negative correlation $(\mathrm{p}>>0.05)$. The normal male $\times$ gold female and gold male $\times$ gold female both gave significant positive correlations $(0.05>\mathrm{p}>0.0 \mathrm{I}$, and $\mathrm{p}<0.0 \mathrm{I}$, respectively).

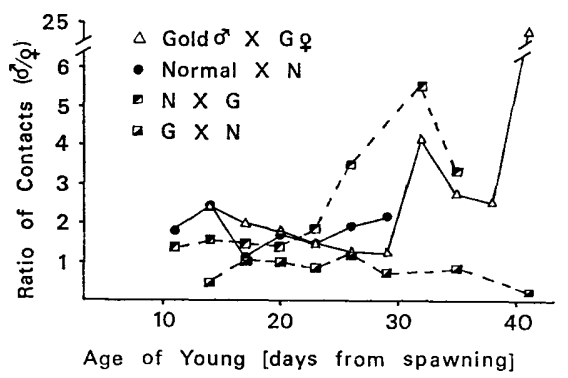

Figure 2. Ratio of contacts $(\hat{\delta} / q)$ for young of different ages, separated according to colors of parents.

Thus we concluded that young fish apparently prefer to contact the male parent, a preference that increases with age of the young fish. Also, the young seem to prefer to contact normal colored parents as opposed to the gold.

\section{RELATIVE SIZE OF PARENTS AND CONTACTING}

As mentioned, the male of a freely mated pair is typically larger than the female. We suspected that the differences in contacting reflected this size discrepancy. Several factors, however, suggest that this is too simple for an adequate explanation.

First, the ratio of contacts (male/female) changes with age of the young, at least in normal male $X$ gold female and in gold male $X$ gold female pairs. This suggests more than a simple surface area relationship.

Second, in gold male $X$ normal female pairs, the young contact the female as much or more than the male, at all ages, even though the males are larger than the females.

Third, in one pair, the male and female were the same size. This pair was 
watched for two parental cycles. The young still contacted the male more than the female, just as in pairs in which the male was larger.

Fourth, there was no obvious relationship between size of the pair and ratio of contacts (male/female). In pairs in which the male was relatively quite large, the ratio of contacts was not consistently high, nor necessarily higher than in pairs in which male and female were closer in size.

The surface area of preserved adult fish of both colors was calculated to compare males and females (Fig. 3). The outlines of each fish, including median fins in natural, semi-erect position, were traced on centimeter graph paper and the area was determined.

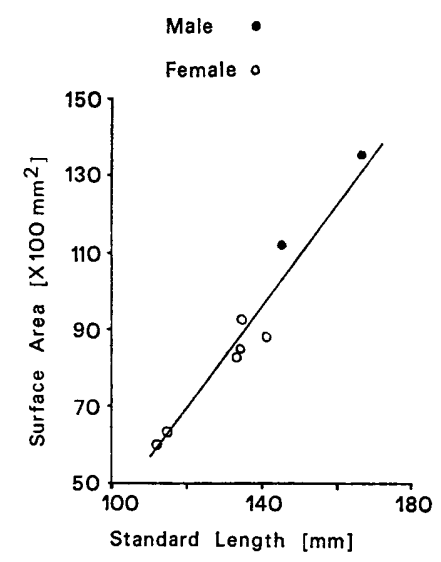

Figure 3. Surface area (one side) of adult fish, plotted against standard length.

For fish in the initial observations, the mean length was $120 \mathrm{~mm}$ for females, I40 mm for males. The corresponding areas are $7000 \mathrm{~mm}^{2}$ and $9625 \mathrm{~mm}^{2}$, respectively. The ratio of these (male/female) is I. 38 . This is about the ratio of contacts (male/female) when young begin contacting, all observations combined (Fig. I). This suggests that initially the young are contacting male and female parents equally on the basis of available surface area. It does not, however, explain the changes in relative amounts of contacting with increasing age of the fry.

From these findings the next steps in the study followed directly. The effects of deprivation from contacting on growth and survival of young fish was the first of the more detailed investigations undertaken.

\section{IS CONTACTING REQUIRED FOR GROWTH AND SURVIVAL?}

Investigations on the effects of deprivation from contacting were planned to explore the role of experience in the formation of contacting preferences. 
The consequences of such deprivation on the growth and survival of young had first to be established. Also, we wanted to compare this aspect to the other known cases of similar behavior in cichlids. With both Symphysodon discus (HILdEMANN, I959) and Etroplus maculatus (WARD \& BARLow, I967). the young apparently have an obligatory relationship to the parents.

Previously, in our laboratory, young had been taken from parents after about one month, reared to adults and had reproduced themselves. Hence, if there is any minimum time the young must spend with parents, it is probably less than this.

Accordingly it was decided that 40 days, post spawning, would be the critical age for this experiment. The null hypothesis was that there would be 110 difference in young raised with or without parents. If this is so, then we can conclude that being with parents and contacting then is not critical for the young kept in aquaria.

\section{PROCEDURE}

Aquaria were of two sizes, for the sake of expediency. One size, hereafter referred to as "large," held about 2401 ( 90 by 60 by $45 \mathrm{~cm}$ deep). The other, hereafter referred to as "small," held about 601 ( 60 by 30 by $30 \mathrm{~cm}$ deep). The glass-walled aquaria were thoroughly cleaned and refilled with fresh water before each experiment. Conditions for all tanks were as similar as possible, and were as described previously.

Aiter spawning, adults were fed mostly dried tropical fish food, in reduced quantities. Almost as soon as they become free swimming young fish begin to eat food given to parents, so the amount of food allowed the parents was reduced to keep young from getting much. Nonetheless, adults gained in length and weight during these experiments.

All young fish were fed newly hatched nauplii (Artemia salina), or occasionally microworms (Anguillula sp.) if the latch of nauplii was inadequate. All groups of young received equal amounts of the same food at each feeding, although the exact amounts varied slightly from day to day. Approximately $2 \mathrm{cc}$ (wet, compressed volume) of nauplii were given at each feeding. The stomachs of the young were visibly distended after feeding, and uneaten nauplii remained in aquaria for an hour or more after feeding. All fish, adults and young, were fed at approximately 0930 and 1630 hours daily.

Since young do not begin contacting until at least Day 3 free swimming, young were taken from the parents on their first day free swimming. Parents were netted from the aquarium, and the tightly schooling mass of young were easily taken in one pass of a large dip net. They were immediately transferred to a shallow glass bowl with water from the hone aquarium. Young were carefully siphoned into groups of 100 each. Each such group was placed either into a large aquarium with one, both, or neither parent; or into a small acuarium with one, or neither parent.

Ten groups of 100 young, five each from two pairs of fish were raised witlout parents in small aquaria. They were counted one group each day, on a rotating schedulc, during the to days. Thus each group was tallied once every tive days.

After 40 days, each aquarium was carefully drained. All young were counted, fixed in $5 \%$ formalin solution, and stored in $50 \%$ isopropyl alcohol. The standard length of each young was measured to the nearest $0.5 \mathrm{~mm}$ under a magnifying lens. 


\section{RESULTS}

Comparing all groups, survival of young raised with parents was just not at the point of being significantly better than for those raised without parents (Table $5 ; \mathrm{p}=0.04, \mathrm{U}$ test). The one-tailed test was applied because the prediction was that young raised with parents should survive better. The losses in fry occurred primarily among the very young; survival thereafter was good (Table 6).

TABLE 5

Suritual of young fish, raised in groups of 100 each $(n=$ number of groups in each category)

$\begin{array}{lcc} & \text { With Parents } & \text { Without Parents } \\ \text { range } & 88-100 & 55-99 \\ \text { median } & 97 & 92 \\ 11 & 7 & 20 \\ & \text { Large Tanks } & \text { Small Tanks } \\ \text { range } & 86-100 & 55-99 \\ \text { median } & 98 & 92 \\ \text { n } & 5 & 22\end{array}$

TABLE 6

Survival of young fish

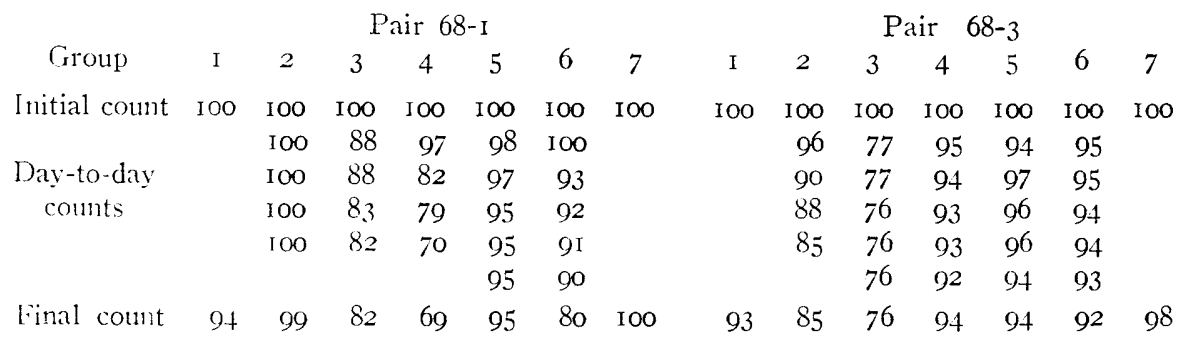

Code: Group I - Small tank, without parents, undisturbed for duration of the experiment.

Groups 2 to 6 - Small tanks, without parents, each counted once every five days.

Group 7 - Large tank, with both parents, undisturbed for the duration of the experiment.

(Note: Some counts are in error since the count on the succeeding day is higher. These are errors in counting live fish. Final counts are for preserved fish and are accurate in all cases.)

For all groups, survival in large tanks was not significantly better than in small tanks (Table $5 ; \mathrm{p}=0.25, \mathrm{U}$ test). The two tailed test was applied here because there was no prediction as to ef fect of tank size on survival. 
For groups raised with parents, survival in large tanks was not significantly different than in small tanks $(\mathrm{p}=0.50$, two-tailed $\mathrm{U}$ test). The same applies to groups raised without parents $(p=0.60$, two-tailed $U$ test $)$.

Fish raised in small tanks, without parents, were significantly shorter than fish raised under the other three conditions (Table 7, Fig. 4; $\mathrm{p}<0.05$, Scheffe's multiple comparison (EDWARDS, 1962)). The lengths of fish raised under the other three conditions were not significantly different from each other $(\mathrm{p}>0.05)$.

\section{TABLE 7}

Standard lengths ( $\mathrm{mm}$ ) of young fish raised in groups of 100 each ( $n=$ number of $f i s h)$

\begin{tabular}{ccccc} 
& \multicolumn{2}{c}{ With Parents } & \multicolumn{2}{c}{ Without Parents } \\
range & large tank & small tank & large tank & small tank \\
mean & I0.0-I9.5 & $9.5-18.0$ & I 3.0-I7.0 & $8.5-17.5$ \\
n & I5.6 & 15.2 & 15.4 & I4.0 \\
& 287 & $34 \mathrm{I}$ & 194 & I455
\end{tabular}

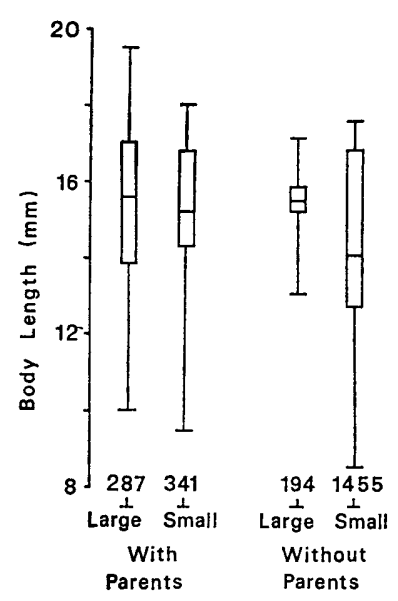

Figure 4. Lengths of young fish, raised in groups of 100 each initially. For each of four classes is shown the overall range, range of means, and class mean; the number of fry in each class is given below each symbol.

Several groups of young, taken from their parents before they began contacting, have been kept for as long as 18 months. Their survival, growth, general behavior and metamorphosis in color have not been apparently different from other young. 


\section{COMMENTS}

Contacting parents is not essential for the growth and survival of young C. citrinellum. However, there are undoubtedly other benefits to the young as a result of being raised with their parents.

One could argue that benefits to the young would not be shown in the unnatural circumstances of the laboratory. But this need not be the case. Parents actively retrieve young and keep them in a compact, closely guarded school, generally toward the middle of the aquarium. Direct observations suggested that mortality of young in these experiments in groups raised without parents was mainly the result of young being trapped inside filters. At times live young were inside filters, and released, especially during their first week of free swimming. Young of this age swam relatively weakly and were scattered throughout the tank. The only aggregations were in corners, often near filter intakes. The only dead young, nonetheless, were found inside filters. But this could be misleading since any dead young would eventually be drawn into the filter.

That contacting is not essential for survival and growth of young C. citriwellum is apparently in contrast to the situation in the other two species $(S$. discus and E. maculatus). This suggests a basic difference in function in the apparently similar behaviors in these species.

If this behavior is not obligatory, why do the young fish do it so regularly and consistently? The most likely possibility is that contacting is an alternate source of nutriment for the young. Our next step, therefore, was to study the relationship between the amount of food given to the young and the amount of contacting they show.

\section{EFFECT OF FEEDING ON CONTACTING}

The plan of these experiments was to have young in two groups and vary the amount fed to each. The amount of contacting by each group to the parent would be measured and any effect of feeding on frequency of contacting would then be seen.

\section{PROCEDURE}

Eight pairs and their young were used, including all colors of parents except gold male $X$ normal female (this cross is difficult to produce, and there was no particular need to do so for this experiment. See Discussion, page 3I for reasons for this difficulty.)

All experiments were in aquaria of approximately 2401 capacity. Water, light, photoperiod, temperature and filtration were as described previously.

Aquaria were set up in pairs, back to back, a few $\mathrm{cm}$ apart (Fig. 5). To simplify scoring, only one parent, the male, was used. Once the pair had spawned and the young were just free swimming, the female was removed. The male was left with roo young in the original breeding tank (called the rear tank). One hundred young were placed into each side of the aquarium in front of the breeding tank (called the front tank). 


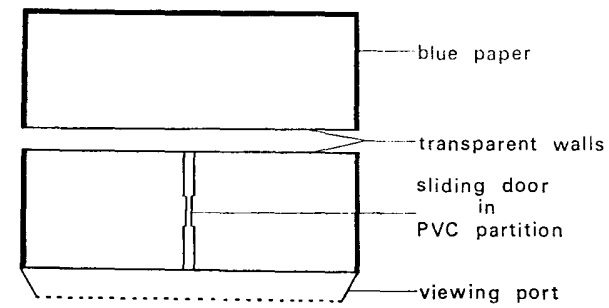

Figure 5. Top view of experimental situation for testing effects of feeding on contacting. Filters, heaters and shelters not shown. (Not exactly to scale).

The two sides of this front tank were completely separated by an opaque PVC partition in which there was a sliding door. A gasket of thin foam rubber sealed around the edges of the partition. Each side had an individual filter and heater.

The male and young in the rear tank were fed at about 0930 hours. At the same time one of the two groups in the front tank (alternated between groups for successive tests) was also fed while the remaining group was not. Each group was given about $2 \mathrm{cc}$ of brine shrimp nauplii. On a few occasions, when there were no nauplii, an equal volume of powdered dry food was given to the young.

At 1400 to 1500 hours, the male was carefully netted from the rear tank and placed gently into one side (determined by the flip of a coin) of the front tank. The male had previously been accustomed to such handling and showed little obvious disturbance. After about one-half hour, a 20-minute observation of contacting was recorded. The male was then shunted to the other half of the tank via the sliding door. About one-half hour later the contacting by this group was recorded. The male was returned to the rear tank at the end of the observations. This was the procedure for the standard tests. In other cases, the male was left with one group of young for two or more successive observations. On other occasions the time at which the young were fed was also varied according to the plan of the experiment.

The paired observations of the standard tests were compared directly to each other. Contacting was recorded as before. However, since there was only one parent present, observations were recorded every ro seconds.

\section{RESULTS}

In every case but one of the paired observations, the unfed group contacted the parent more than did the fed group (Table 8). In this exceptional case, in which the fed group contacted more, the difference was not significant $\left(\mathrm{p}>0.5^{\circ}\right)$; in this test the young had been fed powdered dry food, it had been longer than usual since feeding, and contacting by the fed group was recorded almost one hour after that for the unfed group. (Powdered food had been fed in a few other cases and apparently reduced contacting as well as did nauplii.) Since amount of contacting increases with time since feeding: this probably had an important effect in increasing the amount of contacting shown by the fed group in this test. 


\section{TABLE 8}

Comparison of contacting by fed and unfed groups of young,

in paired observations (age $=$ days free swimming)

Age of Young

Total Contacts

$\begin{array}{rr}8 & 0 \\ 10 & 0 \\ 10 & 0 \\ 10 & 0 \\ 10 & 21 \\ 15 & 77 \\ 17 & 68 \\ 20 & 5 \\ 22 & 52 \\ 24 & 29 \\ 24 & 127 \\ 24 & 18 \\ 27 & 5 \\ 31 & 41 \\ 34 & 3 \\ 36 & 50 \\ 39 & 6 \\ 39 & 23\end{array}$

28
I 3
I04
I 46
I54
I02
I 35
185
96
86
I 18
I 8
33
73
59
222
23
44

$\mathrm{p}$

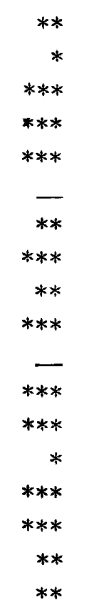

$(-\mathrm{p}>0.05 ; * \mathrm{p} \leqslant 0.05 ; * * \mathrm{p} \leqslant 0.01 ; * * * \mathrm{p} \leqslant 0.00 \mathrm{I})$

Assuming the inverse relation between feeding and contacting, we tested the data for a correlation between time since feeding and amount of contacting.

In one category were observations of young fed on the day of testing. These data (Fig. 6, "Fed") show a significant positive correlation $(\mathrm{p}<\mathrm{O} . \mathrm{OI})$ between time since feeding and amount of contacting.

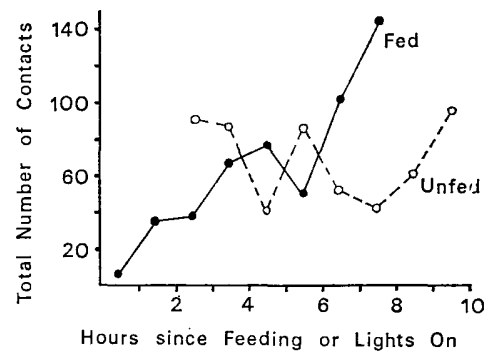

Figure 6. Total contacts (medians for one hour periods) for groups of young, as a function of time. The curve labeled Fed shows the hourly increase after a single feeding;

that labeled Unfed shows the hourly scores after the morning lights came on.

In another category were observations on young not fed on the day of testing. These data were arranged as to the time of the observation (which is directly related to, but not the same as, the time of the last feeding). These 
data (Fig. 6, "Unfed") show no significant correlation $(\mathrm{p}>>0.20)$ between number of contacts and time of day for that observation.

\section{COMMENTS}

The amount of contacting by young $C$. citrinellum varies inversely with feeding. Paired observations indicated that unfed young contact parents more. The inverse relation between feeding and contacting is also shown by the positive correlation between time since feeding and amount of contacting for fed groups of young.

The lack of significant correlation between amount of contacting and time of observation for unfed groups of young makes two points. First, it shows that it is not time of day that is affecting the amount of contacting. By deduction, this means the correlation seen for fed groups of young represents a relation solely between feeding and contacting, with no diurnal rhythm. Second, this suggests there is a limit to the increase in amount of contacting with time since feeding. After some time the amount of contacting no longer increases, but reaches a plateau. This might represent the maximum rate at which young could contact. Alternatively, this could be a continuous reflection of the level of hunger in the young. MarLen \& Hamilton (ig66) referred to the work of Miller (1957) and Tugendhat (I960), and discussed the measurement of hunger in animals. For some measures, there is an initial period of increase, followed by a leveling or slight decrease. For other measures there is only a continuous increase for as long as the animals are deprived of food. Thus there does not seem to be any uniform agreement in single measures of hunger. But the response of these young in their contacting does agree with the first type of measure. Hence, it may indeed be a continuous reflection of their hunger, but we cannot definitely conclude so from this evidence alone.

Both laboratory and field observations suggested an inverse relation between feeding and contacting by the young, and we confirmed this suggestion. Now we moved to a consideration of the preferences which the young show in their contacting, in particular, how these change with the age and experience of the young.

\section{DEPRIVATION FROM CONTACTING AND SUBSEQUENT CONTACTING}

The question we posed now was, "To what extent do the preferences for the male parent and for the normal color pattern result from experience"? This was broken into two simpler questions. (I) What effect does total deprivation from contacting have on contacting behavior at a later date? (2) 
What effect does experience with parents of a particular color have on subsequent contacting preferences? This section describes the experiment undertaken to answer the first of these questions.

Our plan was to isolate one group of young to deprive them of the opportunity to contact the parents. When the control group of young, kept with the parents, had developed a clear preference in their contacting, the isolated young would be exposed to the parents for the first time.

Two alternatives were predicted. If experience is not necessary, then isolated young would show the same preferences as experienced young. If experience is necessary, then isolated young would behave as ordinary young do when they first begin to contact the parents, i.e., they would contact male and female parent equally.

\section{PROCEDURE}

Breeding stock, pretreatment, handling of pairs, and experimental aquaria were as in the experiment on effect of feeding on contacting. There were, however, important differences in experimental design.

As before, aquaria were set up back to back in pairs. However, there was no partition in the front tank. The two tanks were as similar as possible but were separated except for visual contact.

Once a pair had spawned in the rear tank, and the young were just free swimming, all young were removed. One hundred young were replaced into the rear tank with the parents, and 100 placed into the front tank. They had not yet begun contacting parents.

For the young in the rear tank, contacting was recorded as previously during 20-minute observation periods. When these young were showing a consistent and significant preference, the parents were put into the front tank for the first time; this was done in the morning, shortly after the onset of the photoperiod.

Testing started when young were two to three weeks free swimming, with one exception. The gold male $X$ normal female cross was very difficult to produce. When it had been achieved, the time remaining for the study was short, and so these young had to be tested sooner.

The behavior of parents and inexperienced young was monitored more or less continually after putting them together, until the young began to contact the parents. Observations were spoken into a tape recorder for later transcription. Comments were made on general behavior of the fish, position in the tank, and responses of parents to young and vice versa.

As soon as young began contacting, a 20-minute recording was begun to quantify the first contacting of these young. Observations were continued until a consistent and significant sample had been obtained for a 20 -minute period. This usually required no more than two or three recordings on that day for any pair. The parents were returned to the rear tank late in the afternoon.

We attempted to assess the variation introduced by the procedure of moving parents into a different tank to expose them to the isolated group of young. For three of the four pairs observed, contacting by the young in the rear tank was recorded on the day following the moving of the parents to the front tank. By then, the parents had been removed from this tank, kept out eight to ten hours, and then returned. In all cases, the young in the rear tank showed the same preferences in their contacting on the day after as before the move. 
To control for the more immediate effects of handling and introducing the parents into the tank, the following was done once or twice for each pair: The parents were removed from the rear tank first thing in the morning, then immediately returned to the same tank. Apart from a relatively short period of some minutes while the parents and young settled down following this disturbance, there was no apparent effect on contacting preferences of the young. During observations later the same days, the young showed the same preferences as on previous and subsequent days.

This procedure of moving the parents had no apparent effect on contacting preferences of the young during subsequent observations. It is possible, nonetheless, that the procedure could influence total amount of contacting. For example, if parents were more active following the move, or the young more frightened, the total amount of contacting would probably be less. However, this would have no systematic effect on the relative amount of contacting to each parent, since our initial observations showed no correlation between total number of contacts and ratio of contacts to each parent.

These experiments were run in parallel with those of the next section, on the effect of experience, so the same fish were used for both experiments. While it is not difficult to get $C$. citrinellum to spawn in the laboratory, it is difficult to get them to do so with the precision and coordination required in these experiments. It was necessary to have pairs spawn simultaneously since parents were to be interchanged between groups of young. Because of these difficulties, the experiments were limited to one pair for each of the four possible color combinations.

\section{RESULTS}

Despite the small sample size, the differences were clear and consistent, both quantitatively and qualitatively.

On their first opportunity to contact their parents, previously isolated young contacted male and female parents equally often (Table 9). In three pairs the young raised with parents established a significant, consistent preference for the male parent. This agrees with the results for comparable pairs in the initial observations (and confirms the suggested preference for male parent in normal male $X$ normal female pairs). In the other pair gold male $X$ normal female), the young showed a significant, consistent preference for the female parent. This is similar to the results for such pairs in the initial observations, except that for those pairs the preference for the female was not significant.

Although there were differences in detail in the accounts from these different pairs, the essential features were consistent for all observations. These can best be summarized as behavior of parents, and behavior of young.

Parents responded initially to being placed in the front tank by a period of increased swimming. After about one hour the activity of parents was back to normal. During the period of increased activity the parents would 


\section{TABLE 9}

Effects of deprication from contacting on subsequent contacting behavior; first exposure (age $=$ days free swimming)

\begin{tabular}{|c|c|c|c|c|c|}
\hline \multirow[t]{2}{*}{ Parents } & \multirow[t]{2}{*}{ Tank } & \multirow[t]{2}{*}{ Age } & \multicolumn{2}{|c|}{ Contacts to } & $\mathrm{P}$ \\
\hline & & & male & female & \\
\hline \multirow{10}{*}{$\begin{array}{l}\underset{\text { Normal male }}{X} \\
\text { Gold female }\end{array}$} & Rear & + & II & 0 & - \\
\hline & $"$ & 5 & 5 & 0 & 一 \\
\hline & , & 8 & 13 & 8 & - \\
\hline & , & 9 & 54 & 27 & $*$ \\
\hline & ", & IO & 20 & 20 & - \\
\hline & , & II & 32 & 7 & $* *$ \\
\hline & , & 15 & 35 & 5 & $* *$ \\
\hline & ", & I6 & 45 & IO & $* *$ \\
\hline & $"$ & 17 & 57 & 4 & $* *$ \\
\hline & Front & IS & $3 ?$ & $3 I$ & 一 \\
\hline \multirow{11}{*}{$\begin{array}{l}\text { Gold male } \\
\times \\
\text { Gold female }\end{array}$} & Rear & 6 & 19 & 10 & - \\
\hline & , & 7 & 26 & 8 & - \\
\hline & " & 10 & 28 & 12 & $*$ \\
\hline & , & I I & 38 & 10 & $* *$ \\
\hline & " & I 2 & 52 & 15 & $* *$ \\
\hline & $"$ & I3 & 52 & I9 & $* *$ \\
\hline & $"$, & 17 & 137 & I 3 & $* *$ \\
\hline & Front & I8 & I2 & 25 & - \\
\hline & $"$ & I 8 & 7 & I & - \\
\hline & Rear & I9 & 92 & 20 & ** \\
\hline & " & 20 & 72 & 20 & $* *$ \\
\hline \multirow{11}{*}{$\begin{array}{l}\text { Normal male } \\
\times \\
\text { Normal female }\end{array}$} & Rear & I 3 & 45 & 36 & - \\
\hline & ", & It & 9 & II & - \\
\hline & , & It & 12 & 23 & - \\
\hline & $"$ & 15 & 24 & I5 & - \\
\hline & $"$ & 16 & 25 & 20 & - \\
\hline & , & 17 & 39 & 21 & $*$ \\
\hline & " & I 8 & 53 & 21 & ** \\
\hline & " & 20 & 23 & 9 & * \\
\hline & $"$ & 22 & 31 & 12 & $* *$ \\
\hline & Front & 24 & IO & ${ }^{1} j$ & $\overline{-}$ \\
\hline & Rear & 25 & 41 & 15 & $* *$ \\
\hline \multirow{4}{*}{$\begin{array}{l}\text { Gold male } \\
\quad \times \\
\text { Normal female }\end{array}$} & Rear & 10 & 0 & 20 & $* *$ \\
\hline & $"$ & IO & 16 & 55 & $* *$ \\
\hline & Front & II & 9I & $8_{3}$ & - \\
\hline & Rear & 12 & 9 & 27 & $* *$ \\
\hline
\end{tabular}

$(-\mathrm{p}>0.05 ; * \mathrm{p}<0.05 ; * * \mathrm{p}<0.0 \mathrm{I})$ Wilcoxon test

Rear $=$ voung raised with parents

Front $=$ young raised in isolation from parents 
orient toward, or begin to follow, individual young moving about the tank. However, there was never any indication of chasing or attempts to catch these young. When the parents had settled down to the normal activity level, their behavior toward the young seemed normal.

The behavior of the young was also affected immediately by the introduction of the parents. The young at once schooled tightly at or near the surface of the water. This was a marked change from their usual scattered distribution with no clear group cohesion. The young also actively moved away from in front of an approaching parent. After about one hour the young schooled less tightly but still avoided an approaching parent. The young began orienting toward and approaching the parents, from the sides and rear, after about I-I $1 / 2$ to 2 hours. Contacting was first seen after about $2^{I / 2}$ to 3 hours. For some time the young continued to move away from in front of a moving parent. By six hours or so after the parents had been introduced, however, the behavior of young toward them was generally indistinguishable from that of normally experienced young.

\section{COMMENTS}

We can now answer the question about effect of deprivation from contacting. Young so treated contact male and female parents equally on their first opportunity. Hence the experience of contacting parents is necessary for young to develop the preferences they normally show.

This means that these preferences are not solely a result of some change(s) in the parents. Neither are they solely a result of some maturational change in the young. There must be some learning by the young, even if in conjunction with one or both of the above changes. Sight of the parents, by itself, was not sufficient for this learning to take place, suggesting that experience other than visual is involved.

The initial contacting ratio by young is the same, regardless of their age. This raises the questions as to whether or not the young which cannot begin contacting until two or three weeks later than usual would eventually develop the same preferences, and if the preferences would develop at the same rate as in normally experienced young.

We tried to answer these questions, but for technical reasons the attempt was unsuccessful. When a pair of fish was moved to a different tank, there was an increase in overt aggressive acts by one or both parent, as compared to the usual situation in the home tank. These were mostly by the male, directed to the female, and usually no more serious than displaying or restrained attacking, initially at least.

In some instances aggression seemed to increase with time. In the one case 
attempted, a pair was left in the new tank overnight and during the next day. By then the male almost continually threatened or attacked the female, and the responses of the young could not be measured with reliability. Later that day the pair was separated, and the female eventually died of her injuries. Consequently, we did not leave pairs in a new tank for more than one day (up to Io hours) to avoid a continuous strain on the pair bond. Under these circumstances there was no overt fighting.

In our next set of observations we attempted to assess the effect of experience with a particular set of parents on subsequent contacting behavior of young.

\section{EFFECT OF CONTACTING EXPERIENCE ON SUBSEQUENT CONTACTING BEHAVIOR}

From our initial observations we concluded that young show two preferences, one for the male, the other for the normal colored parent. If the young are responding to these features of the parents, we should be able to predict the response to one set of parents as a consequence of the experience of contacting another set of parents. Predicting response of young to their own parents is merely the observations stated in reverse.

If the preferences develop equally in all young, and if experience has no effect, then any group of young should respond the same to a given set of parents. If, however, there is an effect of experience, this would modify the preferences of the young. Any effect of experience would likely be of relatively short duration, since preferences are presumably the same for all young, and hence any young would eventually come to respond equally to a given set of parents.

Take, for example, a group of young with normal male $X$ normal female parents. When the young have been contacting for some time, they will come to contact the male more than the female. If they are actually responding to sex and color of the parents, they will be responding to the male and to normal color (since this is the only color available to them). If these young are now put in with a gold male $X$ normal female pair, they should (initially at least) respond both to male and to normal color, hence they would contact male and female parent equally (or approximately so). However, this is the same response that we would predict if there were no effect of experience.

An important prediction concerns young raised with gold male $\times$ gold female parents. These young will be responding to male and to gold color. When put in with a gold male $X$ normal female pair they should initially contact the male (male + gold) more than the female. This prediction is critical because it says the young would show an effect of experience, and 
would behave differently from young that had been reared with the gold male $X$ normal female. Similarly, if put with normal male $X$ gold female, initially these young (gold $X$ gold) should contact the parents equally. Again this prediction is critical since it says these young will behave differently than young from the normal male $X$ gold female pair, in which case the male is overwhelmingly preferred.

A consideration of all possibilities shows that these latter two are the only critical predictions. They are the only ones that predict cross-fostered young will have preferences different from the parents' own young. Nonetheless, all such transfers of young and observations of their preferences are important because they test the assumption that all young develop the same preferences, based on the same cues.

Although we assumed, for testing, that the preferences for sex and for color of the parents to be equal, we suspected that the preferences for normal color is greater than that for male parent. This derived from our initial observations of gold male $X$ normal female pairs. In these cases, young often contacted the female more than the male, sometimes significantly so (see Discussion).

\section{PROCEDURES}

Since these observations were conducted as part of the previous experiment on deprivation, the fish used, methods of handling, and details of aquaria are identical. The groups of 100 young that were raised with their parents in the rear tanks were the experimental groups for this experiment. They had complete exposure to the parents and were allowed the normal development of contacting.

When the young were showing a significant and consistent preference in their contacting, parents were interchanged with those of another pair with young at a comparable stage. The standard recording technique of 20 -minute observation periods was used for all observations.

Parents were exchanged between families early in the day and the continuous observations were tape recorded. As soon as the young began contacting the parents, a $20-$ minute recording was begun. At least two such observations were recorded, if possible, to get both the initial response and that later on. Parents were returned to their respective home tanks late in the afternoon. Each pair was involved in only one such exchange. Four pairs of fish, one of each possible color combination, were used.

\section{RESULTS}

As will be shown, these results agree with the predictions made by our hypothesis based on the assumption that all young develop the same preferences for the same features of the parents. Further, these results support the suggestion that there is an effect of experience of contacting by the young, and that the preference for the color is greater than that for the sex of the parents.

For young experienced with normal male $X$ gold female and exposed to 
a gold male $X$ gold female pair, our hypothesis assumed that the young had been responding to male and to normal color. Hence when with two fish, both gold, they should have responded to the male more than the female. The results agree with this prediction (Table Io).

TABLE IO

Effects of experience with parents of a particular color on subsequent contacting preferences of young (age $=$ days free swimming)

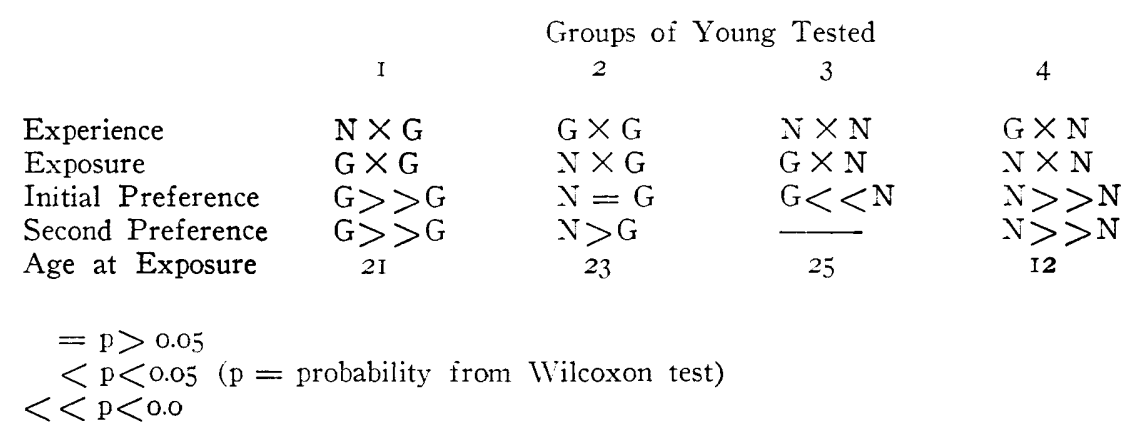

Young, experienced with gold male $X$ gold female, had been responding to male and to gold color. When exposed to normal male $X$ gold female, they should have responded to male and to gold, i.e. they should have contacted male and female equally. This was the case, but by the second observation, the young were contacting the male more than the female (Table Io). Hence the effect of experience is apparently of short duration; the young soon learn to respond to the particular set of parents at hand. As mentioned, there are only two such critical tests as this in this experiment, and this was the only one carried out.

Young, experienced with normal male $X$ normal female were responding to male and to normal color. When exposed to gold male $X$ normal female, they should have contacted the two parents about equally. We suggested that the preference for normal color is greater than that for the male. Accordingly, we would predict here that the young would contact the female more than the male, and they did (Table Io).

Young, experienced with gold male $X$ normal female, were responding to male and to normal color. When exposed to normal male $X$ normal female, these young should have contacted the male (male + color) more than the female, and so they did (Table Io). 


\section{COMMENTS}

The results agree with the predictions. The young are responding to the sex and color of the parents. All young develop the same preferences based on the same features of the parents. The results also agree with the prediction of an effect of experience of contacting a particular set of parents. This effect is readily overcome by the immediate situation. The suggestion that preference for color is greater than that for sex was also reinforced.

With perhaps one important exception, the qualitative behavioral responses of fish were similar to those in the previous experiment on deprivation. In the new tank parents showed an initial period of more rapid swimming, and the occasional fixating on individual fry. As before, after about one hour the behavior of parents appeared typical.

The fry responded to the introduction of foreign parents by schooling tightly, close to the bottom of the tank, and actively moving away from the parents. Again, this contrasted with their usual scattered distribution. Their behavior, however, differed from that of the inexperienced young in the previous experiment. Those young also schooled tightly when the parents were introduced, but they stayed close to the surface of the water. The reason for this difference in behavior of the two kinds of young is not readily apparent.

Within two hours the young were schooling less tightly and beginning to approach the parents. Contacting began after about $2 \frac{1}{2}$ hours. As previously, behavior of the young seemed typical after about five hours.

Only one observation was recorded for young experienced with normal male $X$ normal female, exposed to gold male $X$ normal female. This was because, after two hours or so, the adults began to chase and attempt to eat these foreign young. During these experiments no difficulty was experienced in having parents accept foreign young (i.e. young from a different pair of the same species) of the same age or younger than their own. In this particular case, the foreign young were 13 days older than their own young. In this species it seems that the critical factor for acceptance of young from another pair is the relative age of those young. This aspect of our study will be reported elsewhere (NoAkES \& BarLow, 1973). This points to an area of potential interest in the parental behavior of cichlids. The response of adults is more than just one of "being parental" to young fish, and apparently involves learning of one's own young during each parental cycle.

\section{LIMITATIONS OF METHODS}

There are several limitations which in different ways affected the way we were able to carry out observations, or even the type of observations possible. 
The general difficulties of forming pairs in this species have been alluded to. In addition, there seems to be particular difficulty in forming pairs between fish of certain colors, a pair with gold male $X$ normal female. Gold colored fish dominate normal colored ones of similar size, apparently due to an inhibition of attack by the gold color itself (BarLow, I973). BarLow (1968) and BARLOW \& GREEN ( 1970) have discussed the problems of aggression and fear in courtship in cichlid fishes. No doubt the factors of relative size, aggressiveness, and appeasement are involved in the courtship of $C$. citrinellum, and the added factor of color polymorphism further complicates the issue.

Raising young in isolation, introducing parents to these young, and exchanging parents between families all introduce a different set of limitations. Different pairs must be closely synchronized in their breeding cycles, and care is required to reduce any disturbance that might disrupt the pair bond and/or parental responses. It has been suggested (LoRENZ, I966) that cichlids recognize their mate not only on characters of the individual, but also on features of the immediate environment. Moving a mated pair to a new tank could mean that the fish no longer recognize each other, and the pair might break up. In exchanges of pairs between different tanks we found an increase in aggressive acts by one or both fish, compared to the situation in the home tank, even though the two arenas were virtually the same.

\section{DISCUSSION}

\section{FUNCTION OF CONTACTING}

Survival and growth of young.

Contacting by young $C$. citrinellum, glancing by $E$. maculatus, and clinging by $S$. discus are similar in that all involve young making contact with parents. Although not tested explicitly, there can be little doubt that young $C$. citrinellum remove material from the surface of the parents, as is the case (apparently) in the other two species. They obviously nip at the surface; on occasion they tug back and forth at a bit of material. As they grow, the lesions on the fins and scales of the parents are evidence of the removal of material.

A fundamental difference is that this behavior is not obligatory for the growth and survival of young $C$. citrinellum as it seemingly is for the other species. This means that contacting need not occur, depending on the circumstances.

Contacting and feeding of young.

The initial number of young in a spawn of $C$. citrinellum is large, as many 
as 2,000 or more. The territory of a breeding pair, however, is surprisingly small in most cases. With so many young in a relatively small area, it would be advantageous to have them feed on whatever was available, including material from the parents.

Within an aquarium, even one about as large as a natural territory, presumably there is less food available for the young than in the field. If our explanation of contacting is true, this might explain why we see more contacting, in more species, in the laboratory than in the field.

We would expect the frequency of contacting to vary, depending on numbers and size of young present and amount of food for these young. These factors would vary with individual cases but, in general, species with greater numbers of young and relatively smaller territories would be expected to show the behavior more commonly. This assumes the capability and predisposition for contacting to exist in the species.

The hypothesis that contacting is primarily an alternate source of nutriment could be tested in the field. We have not done this, but our field observations so far support the hypothesis. We found a much lower rate of contacting by young in Lake Jiloá than in Lake Apoyo. The growth of encrusting algae was much more luxuriant in Lake Jiloá, and we assumed there was relatively more food available for the young foraging in this algal growth.

We found that young in smaller aquaria contacted parents more than those in larger aquaria. Parents might be more confined, and so more readily available in smaller tanks, but there would also be relatively less surface area of bottom and sides on which the young could forage.

From an origin as a facultative feeding behavior of the young, contacting could evolve into micronipping or clinging as seen in the other species. If young could feed on material from the parents' bodies, the fish could spawn and raise young in habitats lacking food for the young. For example, if young were staying close to, and feeding from the parents, the family could move about, even up in the water, without regard to suitable foraging areas for the young.

The apparent paradox of young seemingly being dependent on this feeding from parents might also be resolved by this line of reasoning. If young are feeding wholly, or mainly, from the parents, we would expect them to be specialized to this diet (particular digestive enzymes and so on). The analogy between this situation and nursing in mammals has been drawn before. Young mammals are obviously adapted to their nursing diet, and would not do as well on alternate types of food. The analogy might apply here as well. 
In E. maculatus an apparent paradox is that feeding is followed by increased glancing, but there is no obvious influence of hunger on glancing (WARd \& Barlow; I967). Quertermus \& Ward (I969) have since identified two components of glancing; young E. maculatus take material from the parents only during micronipping, and micronipping increases with hunger. It is micronipping of E. maculatus that is comparable to contacting of C. citrinellum. It is unlikely that contacting or similar behavior in New World cichlids and glancing or micronipping in E. maculatus are stages in evolution of this behavior, as the species are widely separated geographically, and not closely related. The similar behaviors are likely convergent from independent origins.

Other functions of contacting.

There could also be other immediate consequences of contacting. The parents obviously respond to contacting, increasingly so with older fry. WARD \& BARLOW (1967) suggested that glancing in E. maculatus might function as feedback maintaining adults in a parental state. This might hold for C. citrinellum. But glancing in E. maculatus comprises two different motor patterns which could well have different functions. We have discussed elsewhere the possible role contacting might play in prolonging parental behavior in C. citrinellum (NoAkes \& BarLow, 1973). The continued presence of young is necessary to maintain adults in the parental state, but the critical stimuli from the young are unknown.

\section{CONTACTING IN OTHER SPECIES}

Further evidence for our considerations of the origin and function of contacting is the presence of similar behavior in other species. It occurs regularly in young Cichlasoma managuense in the laboratory, but rarely, if ever, in the field (pers. observ.). Young $C$. beani show a similar behavior at times in the laboratory (pers. observ.). With rather extreme food deprivation in the laboratory, young C. spilurum behave similarly (SCHEIn, 1968). Stratton (I968) reported that young $C$. spilotum may exhibit such behavior toward parents. Young $C$. nigrofasciatum, on rare occasion apparently show a comparable behavior (A. Myrberg, pers. comm.). Such behavior may be of fairly general occurrence in the genus, but a more regular part of the behavior of some species than others.

Such behavior may even occur among other cichlids. STERBA (I962) referring to Astronotus ocellatus, wrote that "brood care is peculiar in that newly hatched young are carried about attached to the flanks of the parents. However, WARD \& BARLOW ( 1967 ) showed his statements regarding E. maculatus to be in error. His claim deserves further study. 
Finally, there are at least two species of Indian catfish in which young feed on parental skin secretions (Sundara Raj, 1962). The young feed on a proteinaceous secretion from the male.

Epidermal mucus production is increased in parental S. discus (HILDEIIANN, I959) and in E. maculatus (Ward \& Barlow, I967). HEINRICH (1967) noted that parental male Tilapia macrocephala (= melanotheron?) produce much more mucus than nonparental males. The difference can be detected by touch by a blindfolded observer. If young contact the surface of the parents, some of the increased mucus production could result from local irritation, as this is known to increase mucus production (van Oosten, 1957). In the Tilapia, young do not contact the parents, and this could not be so. Because of the correlation between mucus production and parental behavior in $S$. discus and $E$. maculatus, we have begun a preliminary study of scales from C. citrinellum (NOAKES, I973). We also want to see if there is any correlation with maleness or normal color and mucus production.

\section{POSSIBLE BASIS FOR PREFERENCES}

In contacting, young apparently respond to sex and color of the parents. This does not necessarily imply that they are responding to these features per se. They could be responding to some correlate of these. What little we know of the sensory capabilities of young cichlids however, does not make this assumption unreasonable.

KUENZER (1968) reported that color and frequency of movement are the important features of models eliciting responses from young. He found only light-adapted cones in retinas of young, suggesting adaptation to photopic vision. Baerends, Bennema \& Vogelzang (1960) found increasing visual acuity with age of young cichlids. Young $C$. citrinellum obviously respond to visual cues in general behavioral interactions with parents, so it would seem reasonable that at least part of the response to parents might be mediated by visual cues.

KÜHME (1962) has shown that young cichlids can discriminate between con- and heterospecific young solely on the basis of chemical cues in the water. Kühme (1962, I963) and Myrberg (1966) showed that adults were capable of similar discriminations using the same type of chemical cues. There is also some evidence that sound may be used by cichlids in aggressive and parental situations, probably with a communicatory function (MYrBerG, I965; Rodman, I966).

On their first opportunity to do so, young contact both parents equally, irrespective of age. The preferences develop with experience, suggesting a reason other than sensory or motor limitations. It does not necessarily prove this to be the case, however. 
Young could come to show the preferences because they benefit more from contacting a male or normal colored parent. It might be that such parents have more or better material (mucus?) for the young to remove. The results of the tissue study should shed some light here.

The normal color might be a more evocative stimulus for the young. In the parental pattern, a series of strongly contrasting light and dark vertical bars alternate along the sides of the body. Gold colored fish remain the same color at all times. The pattern of bars on the normal colored fish could be more easily perceived by the young, hence attracting them more. However, the fact remains that on first exposure the young go equally to both parents. It is difficult to reconcile the idea that one color is a more evocative stimulus, and yet the young have to learn to respond preferentially to one, or a particular group of stimuli. In our case, it could be that the young are initially responding to the parents through one modality (e.g. chemical cues), and then learning to respond differentially, based on another modality (e.g. visual cues), perhaps by something like associative learning. Myrberg (1966) described such a shift in the response of parental cichlids to young: chemoreception is more important in recognition of wriggling young, while vision is more important in parental discrimination of free-swimming fry.

It might be that the preferences result from negative factors associated with females and gold colored fish. However, this could not be a simple situation, because young prefer a normal female to a gold male. But they also prefer a gold male to a gold female. The evidence regarding the inhibiting effects of the gold color has already been referred to (BARLOW, I973).

Development of preferences.

This development could be due to either (a) changes in the young, and/or (b) changes in the parents.

Changes in the young could be either (I) maturational, and/or (2) learning. The deprivation experiments showed that maturational changes by themselves are not responsible for the development of the preferences. They also indicated that visual experience, alone, is not enough: The inexperienced young had full sight of their parents and of siblings developing the contacting preferences. But these inexperienced fry failed to show the preferences on their first opportunity to contact. As it was not possible to test the rate of development of the preferences in fry of different ages, maturational effects cannot be completely ruled out.

Changes in the parents could also account for the development of the preferences. The behavior of the parents could change, for example, as a result of hormonal changes, such as the female producing a new batch of eggs 
in her ovaries. Or the change could result from experience, in response to the contacting behavior, e.g. the female responding to contacting by avoiding the young.

There could be changes in some other quality of the parents, mucus production being one example. This, in turn, could be related to hormonal changes in the parents.

The deprivation experiments showed that it cannot be just changes in the parents which are responsible for the development of the preferences. Despite differences in age, and hence differences in the stage of the reproductive cycle of the parents, young contact parents equally at their first exposure.

Consequence of preferences.

The experience of contacting the parents could have lasting effects on the young. If imprinting on the parents, or a similar response takes place in the young, the preferences could have important consequences for the species. Such long term effects, if they exist, would probably parallel the preferences in contacting, i.e. a differential responsiveness to sex and color.

Such an effect might be expected to occur in pair formation and mating. It has been mentioned that it is harder to produce a gold male $X$ normal female pair than any other. There are responses of adults to one another, related to the gold color, which could explain the difficulty in producing this cross (BARLow, 1973). However, imprinting by young on sex and color of parents could play a role in this situation, when the young have matured. To answer this possibility would require long term study of fish with known parentage and contacting experience.

Kalmus \& Smith (i966), Seiger (1967) and Seiger \& Dixon (1970) have considered the consequences of imprinting in a polymorphic species. They have presented mathematical models based upon imprinting by young on parents, where individuals will select mates the same color as their parents. In such cases, even if imprinting is only partial, it can act as a mechanism to establish a balanced polymorphism in the population. We think that $C$. citrinellum would be a good species in which to test the predictions of such a model.

\section{SUMMARY}

Adult Cichlasoma citrinellum are polychromatic. About $92 \%$ of the adults of the population studied have a species-typical gray and black color pattern. The other $8 \%$ are partially or completely xanthic.

During the parental phase young nibble at the parents' bodies, apparently eating material from the surface. Such contacting behavior was also observed in nature as a regular phenomenon. Field observations suggested that the young were contacting the 
male parent more than the female, and that the amount of contacting was inversely related to the availability of food for the young.

Contacting is not essential for survival in aquaria. Young raised in isolation from parents have survival and growth not significantly different from those raised with parents.

The amount of contacting by young in aquaria is inversely related to their feeding: Hunger increases the amount of contacting. There is no apparent diurnal rhythm of contacting. Variations are related to the time of feeding.

Contacting is shown by all young in aquaria. Initially young contact male and female parents about equally, regardless of color. At this stage contacting appears to be in proportion to the surface area available on each parent.

Contacting changes with the age of the young. With increasing age, they contact a gray parent progressively more than a xanthic one. Also, they contact the male parent increasingly more than the female. These two preferences are apparently independent.

Young, isolated from their parents in all respects but visually, did not develop preferences in contacting: When first exposed to parents, young fish, regardless of age, contacted each parent relatively the same amount. The continuous sight of their parents and of their siblings developing the contacting preferences was not sufficient for these semi-isolated young to develop the preferences. Hence, this development is not due just to changes in the young and/or the parents, but must involve direct experience.

The experience of contacting a particular set of parents has an effect, of relatively short duration, on subsequent contacting preferences of the young. They learn the color and sex correlated factor of each parent. When tested against other parents, both sex and color play a role, but the natural banded color pattern appears to be more important than maleness.

Parents, in pairs or individually, will accept other young of their species that are the same age or younger than their own. Older young are chased and eaten.

Young can be raised in isolation and successfully re-introduced to their parents. And parents can be exchanged between familics. In both such situations, both parents and young soon settle down and behave in typical fashion toward each other.

The discussion centers on the possible bases for these preferences of the young and their development. Also considered are the origin of contacting as an alternate source of nutriment for the young, and its evolution within the Cichlidae.

\section{REFERENCES}

Baerends, G. P. \& Baerends-van Roon, J. M. (1950). An introduction to the study of the ethology of cichlid fishes. - Behaviour Suppl. I, p. I-242.

- Bennema, B. E. \& Vocelzang, A. A. (I960). Über die Änderung der Sehschärfe mit dem Wachstum bei Aequidens portalagrensis (Hensel) (Pisces, Cichlidae). Zool. Jb. (Syst.) 88, p. $67-78$.

Barlow, G. WV. (Ig68). Effect of size of mate on courtship in a cichlid fish, Etroplus maculatus. - Comm. Beh. Biol. Part A, 2, p. 146-169.

- (1973). Competition between color morphs of the polychromatic Midas cichlid (Cichlasoma citrinellum). - Science (New York) I79, p. 806-807.

- \& GREEN, R. F. (1970). The problem of appeasement and of sexual roles in the courtship behavior of the blackchin mouthbreeder, Tilapia melanotheron (Pisces, Cichlidae). - Behaviour 36 , p. 84-I I5.

Breder, C. M. \& Rosen, D. E. (Ig66). Modes of Reproduction in Fishes. - Nat. Hist. Press, N.Y.

Edwards, A. L. (1962). Experimental Design in Psychological Research. - Holt. Rinehart and Winston, N.Y.

Güvther, A. (I864). On some new species of Central American fishes. - Proc. Zool. Soc. London, I864, p. 23-27.

Behaviour XIVI 
- (1869). An account of the fishes of the states of Central America, based on collections made by Capt. J. M. Dow, F. Goodman, Esq. and O. Salvin, Esq. - Trans. Zool. Soc. London VI, p. 377-494.

Hajlisan, J. P. (1967). The ontogeny of an instinct. The pecking response in chicks of the Laughing Gull (Larus atricilla L.) and related species. - Behaviour Suppl. I5, p. I-I 59 .

HeinRICH, W. (1967). Untersuchungen zum Sexualverhalten in der Gattung Tilapia (Cichlidae: Teleostei) und bei Artbastarden. - Z. Tierpsychol. 24, p. 684-754.

Hildemann, W. H. (I959). A cichlid fish, Symphysodon discus with unique nurture habits. - Amer. Nat. 93, p. 27-34.

HubBs, C. L. \& LAGLER, K. F. (1958). Fishes of the Great Lakes Region. - Cranbrook Institute of Science, Bloomfield Hills, Michigan.

Kalaus, H. \& Smith, S. M. (1966). Some evolutionary consequences of pegmatypic mating systems (imprinting). - Amer. Nat. I00, p. 619-635.

Kruijt, J. P. (1964). Ontogeny of social behaviour in Burmese red jungle fowl (Gallus gallus spadiceus) Bonnaterre. - Behaviour Suppl. I2, p. I-20I.

Kuenzer, P. (1968). Die Auslösung der Nachfolgreaktion bei erfahrungslosen Jungfischen von Nannacara anomala (Cichlidae). - Tierpsychol. 25, p. 257-3I4.

Kuenzer, E. \& Kuenzer, P. (Ig62). Untersuchungen zur Brutpflege der Zwergcichliden Apistogramma reitzigi und $A$. borelli. $-Z$. Tierpsychol. I9, p. 56-83.

KüHmE, W. (1962). Das Schwarmverhalten elterngeführter Jungcichliden (Pisces). Z. Tierpsychol. - I9, p. 513-538.

- (Ig63). Chemisch ausgelöste Brutpflege und Schwarmreaktionen bei Hemichromis bimaculatus (Pisces). - Z. Tierpsychol. 20, p. 688-704.

LoRenz, K. Z. (1966). On Aggression. - Methuen, London.

Marler, P. R. \& Hamilton, W. J. III (1966). Mechanisms of Animal Behavior. Wiley, N.Y.

Mayr, E. (1963). Animal Species and Evolution. - Harvard Univ. Press, Cambridge.

Miller, N. E. (1957). Experiments on motivation. - Science 126, p. I27I-I278.

MYRberG, A. A. (1965). Sound production in cichlid fishes. - Science I49, p. 555-558. (I966). Parental recognition of young in cichlid fishes. - Anim. Behav. I4, p. 565-57I.

NoAkes, D. L. G. (1973). Parental behavior and some histological features of scales in Cichlasoma citrinellum (Pisces, Cichlidae), - Can. J. Zool. (in press).

- \& Barlow, G. W. (1973). Cross-fostering and parent-offspring responses in Cichlasoma labiatum (Pisces, Cichlidae). - Z. Tierpsychol. (in press).

Oosten, J. van (1957). The skin and scales. - In: The Physiology of Fishes, M. E. Brown (Ed.) Vol. I, Metabolism. - Academic Press, N.Y.

Peters, H. M. (1963). Untersuchungen zum Problem des angeborenen Verhaltens. Naturwissen. 22, p. 677-686.

Querteryus, C. J., Jr. \& WARD, J. A. (1969). Development and significance of two motor patterns used in contacting parents by young orange chromides (Etroplus maculatus). - Anim. Behav. 17, p. 624-635.

Rodman, D. T. (I966). Sound production by the African cichlid Tilapia mossambica. Ichthyologica 38 , p. 279-280.

Schein, H. K. (1968). The reproductive behavior of the Central American cichlid fish, Cichlasoma spilurum. - M. A. thesis, Zoology Department, University of California, Berkeley.

SEIGER, M. B. (I967). A computer simulation study of the influence of imprinting on population structure. - Amer. Nat. IOI, p. 47-57.

— \& Dixon, R. D. (1970). A computer simulation study of the effects of two behavioral traits on the genetic structure of semi-isolated populations. - Evolution 24 , p. 90-97. 
Siegel, S. (1956). Nonparametric Statistics for the Behavioral Sciences. - McGrawHill, N.Y.

Sterba, G. (I962). Freshwater Fishes of the World. - Vista, London.

Stratton, E. S. (ig68). Behavior of Cichlasoma spilotum. - M. A. Thesis, Zoology Department, University of California, Berkeley.

Sundara RAJ, B. (I962). The extraordinary breeding habits of the catfish Mystus aor (Hamilton) and Mystus seenghala (Sykes). - Proc. Nat. Institut. Sci. India 28, p. 193-200.

Tugendhat, B. (1960). The normal feeding behavior of the three-spined stickleback (Gasterosteus aculcatus L.). - Behaviour I5, p. 284-318.

WARD, J. A. \& BARLOW, G. W. (I967). The maturation and regulation of glancing off the farents by young orange chronides (Etroplus maculatus; Pisces, Cichlidae). Behaviour 29, p. I -56 .

\section{ZUSAMMENFA:SUNG}

Erwachsene Cichlasoma citrincllum sind polychromatisch. Ca. 92\% der Fische in der untersuchten Population haben ein arttypisches grau-schwarzes Farbmuster, während der Rest entweder ganz oder teilweise gelb ist. Während der Parentalphase knabbern die Jungfische an Körper der Eltern und fressen anscheinend den losgelösten Schleim. Ein solches Kontaktverhalten kommt auch regelmässig in der Natur vor. Freiwasserbeobachtungen liessen vermuten, dass die Jungfische vorzugsweise Kontakt mit dem männlichen Elternteil suchen und dass die Häufigkeit des Kontaktsuchens mit dem Vorhandensein von Nahrung in Beziehung steht. Kontaktverhalten ist im Aquarium jedoch nicht lebensnotwendig, da isoliert aufgezogene Jungfische annähernd die gleiche Uberlebens- und Wachstumsrate haben wie solche, die mit den Eltern zusammen aufwachsen. Die Häufigkeit des Kontaktverhaltens ist ungekehrt proportional zur Nahrungsaufnahme: Hunger steigert das Kontaktverhalten; es unterliegt anscheinend keinem Tagesrhythmus und Unterschiede stehen in Zusammenhang mit der Fütterungszeit. Alle Jungfische zeigen im Aquarium Kontaktverhalten und ursprünglich ist es auf beide Elterntiere gerichtet, ungeachtet der Körperfarbe. In diesem Stadium scheint sich die Kontakthäufigkeit nur nach der Grösse der Körperoberfläche der Elterntiere zu richten.

Das Kontaktverhalten ändert sich mit dem Älterwerden der Jungfische. Mit zunehmendem Alter ziehen sie zunehmend einen grauen Elternfisch einem gelben und das männliche Tier den weiblichen vor. Diese beiden Präferenzen sind anscheinend vonein. ander unabhängig. Isolierte Jungfische, die ihre Eltern jedoch sehen konnten, entwickelten keine Präferenzen im Kontaktverhalten, denn sie berührten jeden Elternfisch gleich oft, wenn sie mit ihnen erstmals zusammengebracht wurden. Die dauernde visuelle Verbindung mit den Elternfischen und den anderen Jungfischen genügte nicht zur Entwicklung einer Präferenz, und direkte Erfahrung ist notwendig. Eine kurzzeitige Kontakterfahrung mit einem bestimmten Elternpaar hat eine Wirkung auf die spätere Präferenzentwicklung bei den Jungfischen. Sie lernen die Farbe und den entsprechenden Geschlechtsfaktor jedes Elternfisches. Geschlecht wie Farbe können eine Rolle spielen, wenn die Jungfische mit anderen Elternpaaren geprüft werden, aber das Streifenmuster scheint wichtiger zu sein als der Faktor 'männliches Geschlecht'. Ein Elternpaar oder ein einzelner Elternfisch akzeptiert auch artgleiche Jung fische einer fremden Brut, vorausgesetzt, dass sie dasselbe Alter haben wie die eigenen; ältere Jungfische werden dagegen gejagt und gefressen. Jungfische können isoliert aufgezogen werden und Eltern sind austauschbar. In beiden Fällen beruhigen sich die Fische bald und zeigen das typische Verhalten zueinander.

Die möglichen Grundlagen fur die Präferenz von Jungfischen wird diskutiert. Der Ursprung und die Evolution des Kontaktverhalten bei Cichliden in Hinsicht auf eine zusätzliche Nahrungsquelle wird besprochen. 